\title{
Article \\ Contamination Assessment of Heavy Metals in Agricultural Soil, in the Liwa Area (UAE)
}

\author{
Ahmed A. Al-Taani ${ }^{1,2} \mathbb{D}^{\mathbb{D}}$, Yousef Nazzal ${ }^{1} \mathbb{D}$, Fares M. Howari ${ }^{1} \mathbb{D}$, Jibran Iqbal ${ }^{1} \mathbb{D}$, Nadine Bou Orm ${ }^{1} \mathbb{D}$, \\ Cijo Madathil Xavier ${ }^{1}$, Alina Bărbulescu ${ }^{3, * \mathbb{D}}$, Manish Sharma ${ }^{1}$ and Cristian-Stefan Dumitriu ${ }^{4, *}$ \\ 1 College of Natural and Health Sciences, Zayed University, Abu Dhabi 144534, United Arab Emirates; \\ Ahmed.Al-Taani@zu.ac.ae (A.A.A.-T.); yousef.nazzal@zu.ac.ae (Y.N.); fares.howari@zu.ac.ae (F.M.H.); \\ Jibran.Iqbal@zu.ac.ae (J.I.); nadine.bouorm@zu.ac.ae (N.B.O.); Cijo.Xavier@zu.ac.ae (C.M.X.); \\ manish.sharma@zu.ac.ae (M.S.) \\ 2 Department of Earth and Environmental Sciences, Yarmouk University, Irbid 21163, Jordan \\ 3 Transilvania University of Brasov, 5 Turnului Str., 500036 Brasov, Romania \\ 4 S.C. Utilnavorep S.A., 55 Aurel Vlaicu Bd., 900055 Constanta, Romania \\ * Correspondence: alinadumitriu@yahoo.com (A.B.); cris.dum.stef@gmail.com (C.-S.D.)
}

Citation: Al-Taani, A.A.; Nazzal, Y.; Howari, F.M.; Iqbal, J.; Bou Orm, N.; Xavier, C.M.; Bărbulescu, A.; Sharma, M.; Dumitriu, C.-S. Contamination Assessment of Heavy Metals in Agricultural Soil, in the Liwa Area (UAE). Toxics 2021, 9, 53. https:// doi.org/10.3390/toxics 9030053

Academic Editor: Lucica Barbes

Received: 18 February 2021

Accepted: 8 March 2021

Published: 10 March 2021

Publisher's Note: MDPI stays neutral with regard to jurisdictional claims in published maps and institutional affiliations.

Copyright: (c) 2021 by the authors. Licensee MDPI, Basel, Switzerland. This article is an open access article distributed under the terms and conditions of the Creative Commons Attribution (CC BY) license (https:// creativecommons.org/licenses/by/ $4.0 /)$.

\begin{abstract}
The Liwa area is a primary food production area in the United Arab Emirates (UAE) and has intensively been used for agriculture. This study investigates the pollution levels with heavy metals in agricultural soils from the Liwa area. Thirty-two soil samples were analyzed for $\mathrm{Mn}, \mathrm{Zn}$, $\mathrm{Cr}, \mathrm{Ni}, \mathrm{Cu}, \mathrm{Pb}, \mathrm{Cd}, \mathrm{Co}$, and As. Results revealed that heavy metal levels varied in the ranges 220.02311.21, 42.39-66.92, 43.43-71.55, 32.86-52.12, 10.29-21.70, 2.83-8.84, 0.46-0.69, 0.03-0.37 mg/kg for $\mathrm{Mn}, \mathrm{Zn}, \mathrm{Cr}, \mathrm{Ni}, \mathrm{Cu}, \mathrm{Pb}, \mathrm{Cd}, \mathrm{Co}$, and As, respectively. All samples presented low As concentrations with an average of $0.01 \mathrm{mg} / \mathrm{kg}$. The variations in bulk metal contents in the soil samples were related to multiple sources, including agrochemicals, atmospheric dust containing heavy metals, and trafficrelated metals. Enrichment factor analysis indicates that $\mathrm{Cd}, \mathrm{Ni}, \mathrm{Zn}$, and $\mathrm{Cr}$ were highly enriched in soils, and they could originate from non-crustal sources. Based on the geo-accumulation index $\left(\mathrm{I}_{\text {geo }}\right)$, the soil samples appeared uncontaminated with $\mathrm{Mn}, \mathrm{Cr}, \mathrm{Zn}, \mathrm{Pb}, \mathrm{Co}, \mathrm{As}, \mathrm{Cu}$, uncontaminated to moderately contaminated with $\mathrm{Ni}$ and moderately contaminated with $\mathrm{Cd}$. The contamination factors suggest low contamination, except for $\mathrm{Ni}$, which showed moderate contamination. The average pollution load index (PLI) revealed unpolluted to low pollution of all soil samples. The ecological risk assessment (PERI) showed that all heavy metals posed a low risk, except for Cd which exhibited a high ecological risk.
\end{abstract}

Keywords: soil; agriculture; pollution indices; heavy metals; ecological risk assessment; Liwa; Abu Dhabi; UAE

\section{Introduction}

Soil pollution with toxic heavy metals gained growing attention in recent years due to increasing human activities and expanding the industrial and transportation sectors. Urbanization has also influenced soil properties not only in the surrounding areas but also at a distance. Heavy metals are mostly toxic, persistent, and bioaccumulative. They tend to accumulate in soils [1-3], and transmit to the plants' parts, which action as bioaccumulators [4-7]. The ingestion of contaminated food has adverse effects on the human health, especially on children [8-13]. The USEPA [14] listed several heavy metals as hazardous air pollutants such as $\mathrm{Pb}, \mathrm{Co}, \mathrm{Mn}, \mathrm{Ni}, \mathrm{Cd}$, and $\mathrm{Cr}$, of which $\mathrm{Cd}, \mathrm{Cr}$, and $\mathrm{Ni}$ have been included in the carcinogenic category.

Chemical compounds and heavy metals may lead to degradation or loss of some soil functions and services. Heavy metal pollution is largely irreversible [15-20]. The geology, geographical characteristics, and local climate are considered the main natural factors that influence the heavy metal dispersion in the environment. Heavy metals have a 
long residence time because of the interactions with particular soil components [21]. The chemical forms and metal speciation are essential factors for the fate and transport of heavy metals in soils [22], that may affect the aquifer quality as well [23]. Atmospheric deposition contributes to heavy metals accumulation in soils. While they are naturally occurring elements in the earth's crust, human activities can increase their levels and distribution in the environment and accelerate their release from natural sources. Anthropogenic sources such as industrial emissions, fuel combustion, waste management, and transport are the most important [22,24-26]. Different authors pointed out the contribution of mining activities to the soil pollution, especially with heavy metals [27-30].

While a large number of publications have assessed heavy metals in urban soils [17,26,31-35], their status and impacts on remote soils have received less attention. The presence of heavy metals in sediments [25,36], dust [36,37] and in coastal areas [38] is considered to be a good indicator of soil contamination $[2,26]$.

In arid regions, soil contamination with heavy metals may have different sources and pathways. Arid climates with frequent dust storms can cause heavy metals dissipation at long distances [2,39]. Elevated levels of metals were found in remote areas in arid regions and have been linked to atmospheric dust containing metals [3], among others. Besides, the fossil fuel burning explains the the input of heavy metals in some remote areas [2].

Liwa is an area in the southern UAE with a major groundwater reserve. It has been used intensively for agricultural activities. The groundwater vulnerability assessment of the Liwa's groundwater indicated that the aquifer beneath is highly vulnerable to pollution [31].

The goal of this research is to check the hypothesis of the soil possible contamination with heavy metals in the Liwa area (Abu Dhabi Emirate). For a correct estimation of the pollution degree different indicators suggested in the literature [40-43] are used, and comparisons of results are provided. The potential sources of pollution in the area are emphasized, including agricultural activities. This study could provide additional information about the potential impact and consequences on the major groundwater aquifer in the region. This research could help the policy makers sustainably regulate the agricultural activities and adopt measures for improving crop production (because this area is the leading food producer of the UAE) and protecting the groundwater aquifer.

\section{Description of the Study Area}

The study area is located in Liwa, south of Abu Dhabi, in the UAE (Figure 1). It is a sparsely populated area, where agriculture is the common land use (Figure 2). 


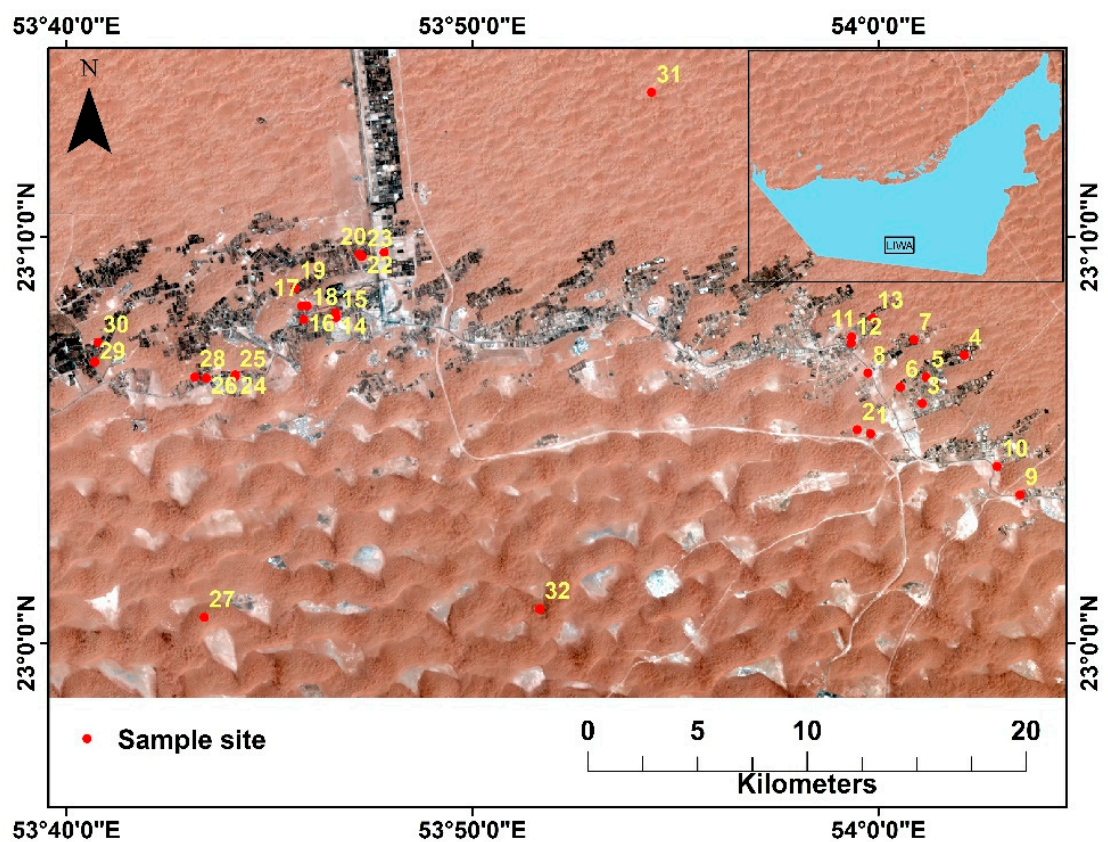

Figure 1. Location map of the study area and sampling sites, Liwa, Abu Dhabi.

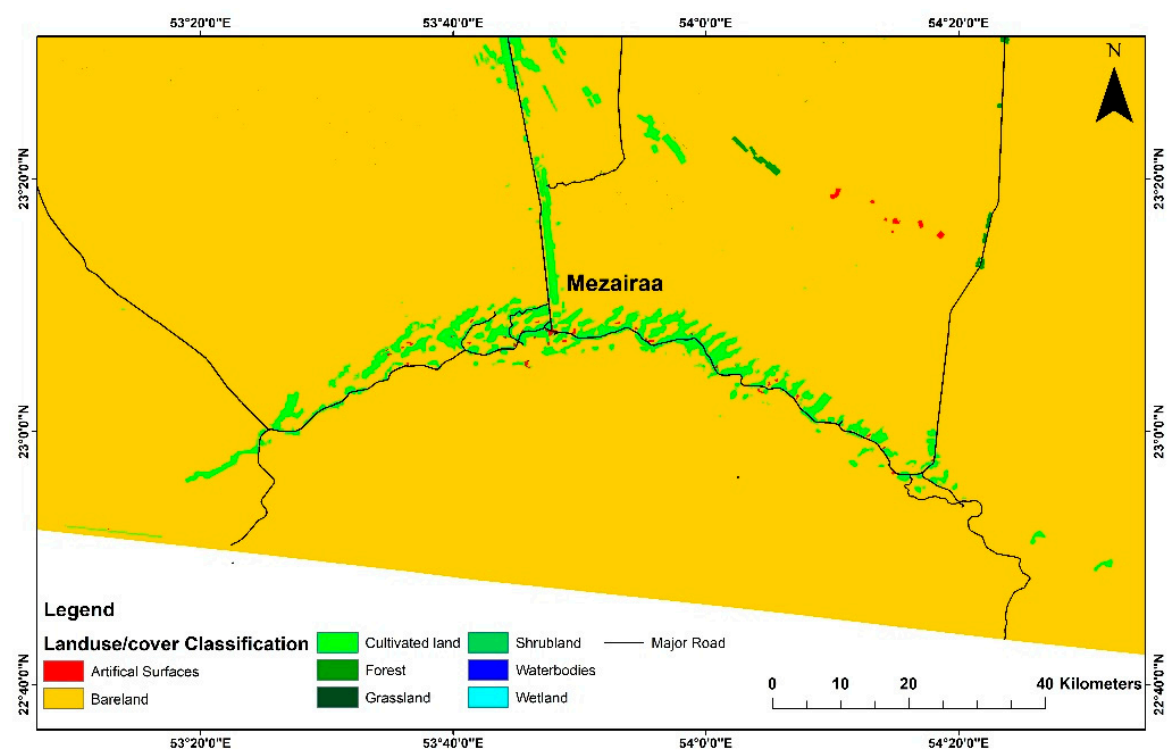

Figure 2. Land use/cover distribution map of the study area, Liwa, Abu Dhabi.

Abu Dhabi has an arid climate with a highly variable and erratic rainfall of less than $100 \mathrm{~mm}$ /year, occurring mainly in winter. The annual evaporation rate in the study area is considerably high.

This area hosts a major groundwater aquifer, with a nominal groundwater recharge rate ( $4 \%$ of total annual water use) and no surface water resources. This shallow aquifer system in Abu Dhabi Emirate has been overused for irrigation, where the study area has one of the Emirate's most extensive cultivated lands [44]. In addition to the intensive agriculture, desert greening has exerted additional pressure on the groundwater reserve. The main groundwater aquifers and agricultural fields are located adjacent to the main highway (between Madinat Zayed and Meziyrah), delineating the Liwa's eastern boundary (Figure 2).

Evidence of groundwater quality degradation in the Liwa region has been reported and was attributed mainly to agricultural activities $[45,46]$. Shallow groundwater table and 
the high evaporation are other factors contributing to the deteriorating groundwater quality. Low groundwater table in this area, due to widespread irrigation, has been reported by Iqbal et al. [46].

\section{Materials and Methods}

A total of 32 soil samples were collected during February 2019 from several farming areas located in the Liwa area in UAE (Figure 1). The samples were collected from the upper $10 \mathrm{~cm}$ in labelled polyethylene bags. Soil samples were grinded, sieved through $2 \mathrm{~mm}$ mesh in the laboratory, and stored in plastic bags. $200 \mathrm{mg}$ were digested in dry and clean Teflon digestion beaker, and $6 \mathrm{~mL} \mathrm{HNO}_{3}, 2 \mathrm{~mL} \mathrm{HCl}$ and $2 \mathrm{~mL} \mathrm{HF}$ were added, and the mixture was heated for $40 \mathrm{~min}$ on a hot plate at $120-150^{\circ} \mathrm{C}$. The mixture was filtered through Whatman filter paper No. 42 and the filtered digest was transferred to a $50 \mathrm{~mL}$ plastic volumetric flask and filled up to the mark by deionized water. Metal contents were measured by Agilent 700 series ICP-OES. A Certified Reference Material (CRM) (IAEA SOIL-7) was used to validate the analytical measurement methods. Table 1 shows the recovery results (in \%) which ranges from $97-109 \%$, indicating a high accuracy of the method used in this study.

Table 1. The accuracy and precision of the analytical method applied to the multi-element determination of soil samples.

\begin{tabular}{ccccc}
\hline Element & Mass & $\begin{array}{c}\text { Certified Value } \\
(\mathbf{m g} / \mathbf{K g})\end{array}$ & $\begin{array}{c}\text { Measured Value } \\
(\mathbf{m g} / \mathbf{K g})\end{array}$ & Recovery (\%) \\
\hline $\mathrm{Mn}$ & 55 & 631 & 641.1 & 101.6 \\
\hline $\mathrm{Zn}$ & 66 & 104 & 101.94 & 98.02 \\
\hline $\mathrm{Cr}$ & 52 & 60 & 61.71 & 102.85 \\
\hline $\mathrm{Ni}$ & 60 & 26 & 26.76 & 102.92 \\
\hline $\mathrm{Cu}$ & 63 & 11 & 10.82 & 98.36 \\
\hline $\mathrm{Pb}$ & 208 & 60 & 61.6 & 102.67 \\
\hline $\mathrm{Cd}$ & 111 & 1.3 & 1.31 & 100.77 \\
\hline $\mathrm{Co}$ & 59 & 8.9 & 9.76 & 109.66 \\
\hline $\mathrm{As}$ & 75 & 13.4 & 14.01 & 104.01 \\
\hline
\end{tabular}

* The mean of five consecutive samples.

Heavy metal pollution in soils was assessed using the Enrichment factor (EF) of Sinex and Helz [47], as follows:

$$
\mathrm{EF}=(\mathrm{M} / \mathrm{Fe})_{\text {sample }} /(\mathrm{M} / \mathrm{Fe})_{\text {crust }} \text {, }
$$

where $(\mathrm{M} / \mathrm{Fe})_{\text {sample }}$ is the ratio of metal and Fe concentrations in the sample, and $(\mathrm{M} / \mathrm{Fe})_{\text {crust }}$ is the ratio of metal and Fe concentrations in the Earth's crust $[48,49]$. Metals with EF $<2$ are considered to originate entirely from the crustal materials or natural processes, while those with EF $>2$ are most likely the product of anthropogenic activities [50].

Heavy metals in soils were also evaluated using the geoaccumulation index $\left(\mathrm{I}_{\text {geo }}\right)$ [51]. It is expressed as:

$$
\mathrm{I}_{\text {geo }}=\log _{2}\left[\mathrm{C}_{n} /\left(1.5 B_{n}\right)\right],
$$

where $C_{n}$ is the measured concentration of the examined metal $n$ in the soil, and $B_{n}$ is the geochemical background concentration (or reference value) of the metal $n$. The constant 1.5 accounts for the natural fluctuations of the metal in soil. The mean contents of the global geochemical background of Cambisols (silty and loamy soils) [49] and the average crustal abundance [52] were used. The $I_{\text {geo }}$ has seven grades (0 to 6), indicating various degrees of enrichment above the background values and ranging from unpolluted to very highly polluted soil quality. 
The contamination factor (CF) for soil samples were assessed to quantify the impact of each metal on the soil $[53,54]$. The CF was calculated by dividing the heavy metal concentration of soil by the background value of reported by Kabata-Pendias [49].

The pollution degree was further assessed by the pollution load index (PLI). The PLI of each metal was computed as follows:

$$
\mathrm{PLI}=\left(\mathrm{CF}_{1} \times \mathrm{CF}_{2} \times \ldots \times \mathrm{CF}_{\mathrm{n}}\right)^{1 / \mathrm{n}},
$$

where CF is the calculated contamination factor, $n$ is the number of heavy metals (nine in the present study) [55-57]. The PLI of each metal was classified as polluted (PLI > 1), or within the baseline level (PLI = 1), whereas PLI $<1$ indicates no pollution [56].

The potential ecological risk index was computed to assess the cumulative pollution effects of multiple metal on the soils. The formula developed by Håkanson [54] was used, as follows:

$$
\begin{aligned}
& \text { PERI }=\sum \mathrm{E}_{\mathrm{i}}, \\
& \mathrm{E}_{\mathrm{i}}=\mathrm{T}_{\mathrm{i}} \times \mathrm{CF}_{\mathrm{i}},
\end{aligned}
$$

where $E_{i}$ is the single ecological risk index, $T_{i}$ is the toxic response factor for a given metal, $i$ (e.g., $\mathrm{Cd}=30, \mathrm{Mn}=\mathrm{Zn}=1, \mathrm{~Pb}=\mathrm{Ni}=\mathrm{Co}=\mathrm{Cu}=5, \mathrm{As}=10$, and $\mathrm{Cr}=2$ ) [51], $\mathrm{CF}_{\mathrm{i}}$ is the calculated contamination factor for the metal $I, \mathrm{E}_{\mathrm{i}}<40$ indicates low contamination, whereas $40 \leq E_{i}<80,80 \leq E_{i}<160,160 \leq E_{i}<320$, and $E_{i} \geq 320$ shows a moderate, considerable, high, or significantly high contamination risk, respectively [54] and $\mathrm{CF}_{\mathrm{i}}$ indicates a low $\left(\mathrm{CF}_{\mathrm{i}}<1\right)$, moderate $\left(1 \leq \mathrm{CF}_{\mathrm{i}}<3\right)$, considerable $\left(3 \leq \mathrm{CF}_{\mathrm{i}}<6\right)$, or very high contamination $\left(\mathrm{CF}_{\mathrm{i}} \geq 6\right)$ [54].

The PERI has four grades, corresponding to values smaller than 150 (low), from 150-300 (moderate), in the range of 300-600 (considerable), and greater than or equal to 600 (very high) [54].

\section{Results and Discussion}

The summary of the statistical analysis of heavy metal concentrations in the soil samples is presented in Table 2. Heavy metal levels varied from 220.02-311.21, 42.39-66.92, 43.43-71.55, 32.86-52.12, 10.29-21.70, 2.83-8.84, 0.46-0.69, 0.03-0.37 for Mn, Zn, Cr, Ni, Cu, $\mathrm{Pb}, \mathrm{Cd}$, and $\mathrm{Co} \mathrm{mg} / \mathrm{kg}$, respectively. The metals concentrations are slightly variable, with the highest variability observed for $\mathrm{Co}$ followed by $\mathrm{Pb}$ (with coefficients of variation of 0.45 and 0.32 , respectively). Low levels were observed in all soil samples averaging of $0.01 \mathrm{mg} / \mathrm{kg}$ ) (Table 2).

Table 2. Metal concentrations (mg/kg) in the soil samples collected from Liwa, Abu Dhabi. SD is the standard deviation and $\mathrm{CV}$ is the coefficient of variation.

\begin{tabular}{ccccccc}
\hline & Mean & Min & Max & SD & Median & CV \\
\hline $\mathrm{Mn}$ & 273.9 & 220.02 & 311.21 & 21.49 & 277.22 & 0.08 \\
$\mathrm{Zn}$ & 54.08 & 42.39 & 66.92 & 7.47 & 54.07 & 0.14 \\
$\mathrm{Cr}$ & 59 & 43.43 & 71.55 & 7.85 & 58.5 & 0.13 \\
$\mathrm{Ni}$ & 40.83 & 32.86 & 52.12 & 5.74 & 39.24 & 0.14 \\
$\mathrm{Cu}$ & 14.17 & 10.29 & 21.7 & 2.68 & 14.07 & 0.19 \\
$\mathrm{~Pb}$ & 5.28 & 2.83 & 8.84 & 1.72 & 4.89 & 0.32 \\
$\mathrm{Cd}$ & 0.58 & 0.46 & 0.69 & 0.06 & 0.58 & 0.11 \\
$\mathrm{Co}$ & 0.18 & 0.03 & 0.37 & 0.08 & 0.17 & 0.45 \\
$\mathrm{As}$ & 0.016 & 0.01 & 0.01 & 0.01 & 0.01 & 0.06 \\
\hline
\end{tabular}

The highest concentration was that of Mn, with mean and median concentrations of 273.9 and $277.22 \mathrm{mg} / \mathrm{kg}$, respectively. The concentrations of the other heavy metals, in decreasing order, are $\mathrm{Cr}>\mathrm{Zn}>\mathrm{Ni}>\mathrm{Cu}>\mathrm{Pb}>\mathrm{Cd}>\mathrm{Co}>$ As (Figure 3 and Table 2). 


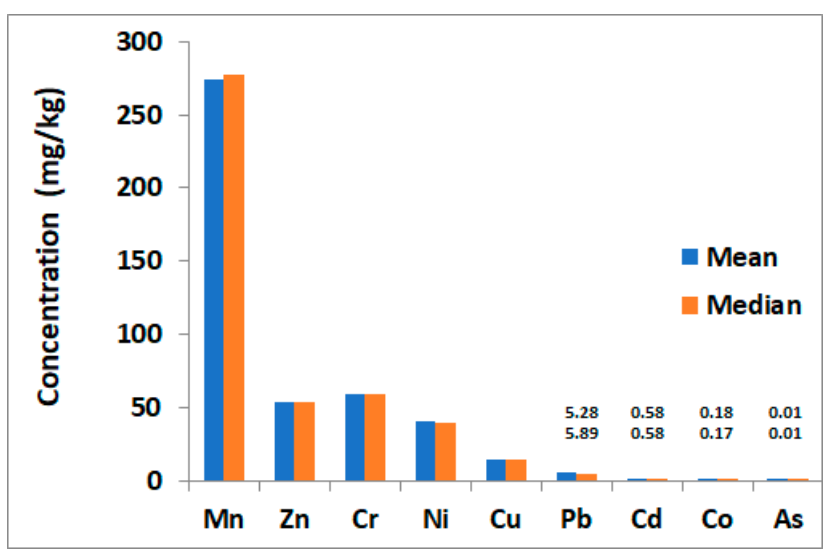

Figure 3. Mean and median concentrations $(\mathrm{mg} / \mathrm{kg})$ of heavy metals in the soil samples collected from Liwa, Abu Dhabi.

The variations in concentrations of bulk metals in the soil samples are related to multiple sources. This region hosts the largest groundwater aquifer in the UAE and has intensively been used for agricultural production (Figure 2). Agrochemicals may contribute to heavy metals accumulation in soils (such as $\mathrm{Cu}, \mathrm{Zn}, \mathrm{Fe}, \mathrm{Mn}$, and As) [22]. Elevated levels of $\mathrm{Cd}, \mathrm{As}$, and $\mathrm{Pb}$ have been associated with applications of phosphate fertilizers [58].

The compost is frequently used in the UAE to enhance the soil properties and improve its fertility since infertile sandy soils are widespread in the UAE. The use of compost (and other biosolids such as livestock manure and municipal sewage sludge) have been reported to increase the concentration of certain metals ( $\mathrm{As}, \mathrm{Cd}, \mathrm{Cr}, \mathrm{Cu}, \mathrm{Pb}, \mathrm{Hg}, \mathrm{Ni}, \mathrm{Se}, \mathrm{Mo}, \mathrm{Zn}, \mathrm{Tl}, \mathrm{Sb}$, etc.) in soils [59]. These metals can be released from the compost and other biosolids to the soils and can end up in the groundwater aquifers [60-63]. Enriched soil with metals (such as $\mathrm{Cu}, \mathrm{Zn}, \mathrm{Ni}, \mathrm{Pb}, \mathrm{Cd}$, and $\mathrm{Cr}$ ), as a result of repeated application of biosolids, has been reported $[64,65]$. The frequent use of fungicides and pesticides has also been associated with the accumulation of heavy metals (such as $\mathrm{Cu}, \mathrm{Zn}, \mathrm{Pb}$, and $\mathrm{As}$ ) in soils [64-67].

Intensive agricultural production is commonly practiced in this region, where groundwater is the sole source of irrigation water. Salinization and contamination with chemicals were observed in groundwater [39,46]. The soils' compositions revealed greater concentrations of $\mathrm{Ca}, \mathrm{Mg}$, Na and $\mathrm{K}$ (Figure 4) that are attributed to overirrigation with salty groundwater, weathering of carbonates and evaporites rocks that are widespread in this region.

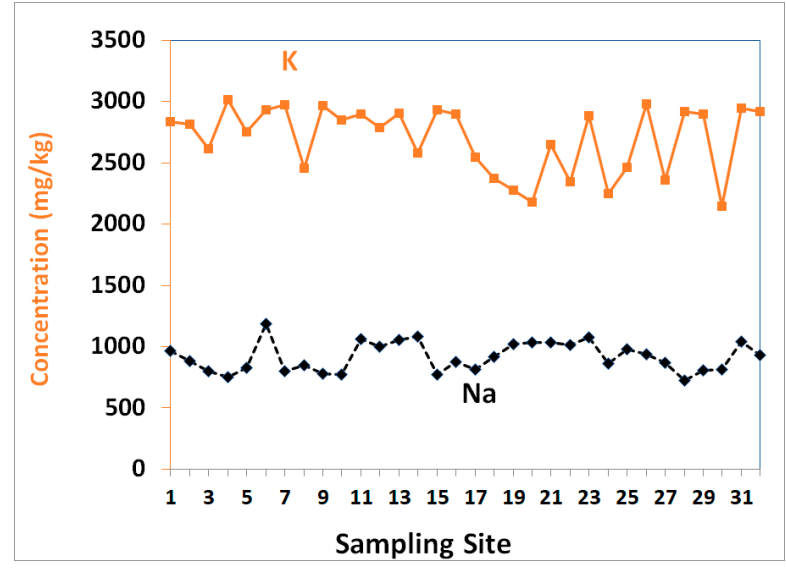

(a)

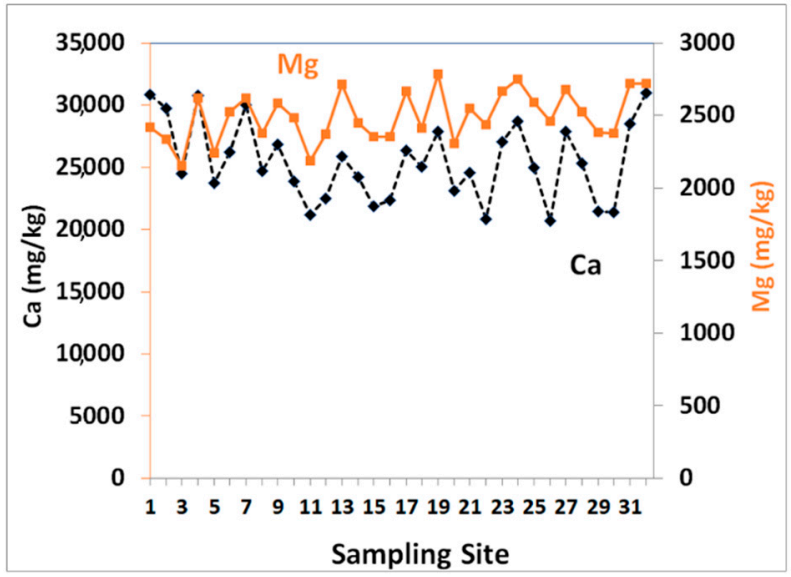

(b)

Figure 4. The concentrations of (a) $\mathrm{Na}$, and $\mathrm{K},(\mathbf{b}) \mathrm{Ca}$ and $\mathrm{Mg}$ in the soil samples collected from Liwa. 
The Liwa region's vulnerability assessment indicated that the aquifer beneath the extensive agriculture area is highly vulnerable to pollution [39]. It indicates that heavy metals in soils may leach with agricultural runoff to end up in the groundwater.

The study area is also bordered by a major traffic highway, with impacts from vehicular emissions. $\mathrm{Cd}, \mathrm{Pb}$, and $\mathrm{Zn}$ in soils could originate partly from traffic activities [24,68-70]. Elevated levels of heavy metals were observed in roadside dust samples collected from Abu Dhabi, particularly $\mathrm{Cr}, \mathrm{Pb}, \mathrm{Zn}$, and $\mathrm{Mn}$ [2] (Table 3). However, sediment samples collected from the coastal area of Abu Dhabi further from the major highway showed low concentration [71] (Table 3). This suggests that ambient dust is probably an important source and pathway of metals to the soil in Liwa.

Heavy combustion of fossil fuel is another potential source contributing to heavy metals' measured values in soil (especially $\mathrm{Cd}, \mathrm{Zn}, \mathrm{As}, \mathrm{Cu}, \mathrm{Mn}$ ), where the study area is located near gas and oil fields in the southern UAE. Also, the Arabian Peninsula (including the UAE) hosts leading oil and petrochemical industries. These world's industries can add metals to the ambient dust, where the northerly wind carries airborne emissions to the UAE $[2,3]$.

Table 3. Heavy metals concentration $(\mathrm{mg} / \mathrm{kg})$ in this study compared to their averages in the upper continental crust, worldwide soils, and coastal sediments and roadside dust in Abu Dhabi.

\begin{tabular}{cccccc}
\hline & $\begin{array}{c}\text { Present } \\
\text { Study }\end{array}$ & $\begin{array}{c}\text { Continental } \\
\text { Crust } \\
{[48,49]}\end{array}$ & $\begin{array}{c}\text { Worldwide } \\
\text { Soils } \\
{[49]}\end{array}$ & $\begin{array}{c}\text { Abu Dhabi } \\
\text { Coastal } \\
\text { Sediment } \\
{[71]}\end{array}$ & $\begin{array}{c}\text { Abu Dhabi } \\
\text { Roadside } \\
\text { Dust [2] }\end{array}$ \\
\hline $\mathrm{As}$ & 0.01 & 1.8 & 6.83 & 1 & 0.23 \\
$\mathrm{Cd}$ & 0.58 & 0.1 & 0.41 & 0 & 0.48 \\
$\mathrm{Cr}$ & 59 & 100 & 59.5 & - & 306.3 \\
$\mathrm{Co}$ & 0.18 & 10 & 11.3 & 4.1 & - \\
$\mathrm{Cu}$ & 14.17 & 55 & 38.9 & 3.8 & - \\
$\mathrm{Pb}$ & 5.28 & 15 & 27 & 1.9 & 50.05 \\
$\mathrm{Ni}$ & 40.83 & 20 & 29 & 25.3 & 0.3 \\
$\mathrm{Zn}$ & 54.08 & 70 & 70 & 8.2 & 173.0 \\
$\mathrm{Mn}$ & 273.9 & 900 & 488 & - & 1158.5 \\
\hline
\end{tabular}

The electric power industry is the backbone of the UAE economic sectors and is expanding rapidly. The UAE's energy consumption rate is one of the highest globally [72]. Natural gas-fueled power plants are essential contributors to the metal concentration in the ambient air, and consequently, to the measured values of heavy metals in soil, through dust deposition. Heavy oil and diesel are occasionally used in power plants [73].

Dust storms are common in the UAE, contributing to the transport and deposition of the metals to soil $[2,11]$. The UAE is in a desert-belt region with intense and frequent dust storm events, where the surrounding deserts are the major sources of mineral dustcontaining heavy metals [2,3]. Regional deserts (in Iran, Pakistan) are likely to contribute to long-range atmospheric dust in the UAE [74].

While the composition of soils revealed generally much greater concentrations for Mn, $\mathrm{Zn}, \mathrm{Cr}$, and $\mathrm{Ni}$ than other metals, only the concentration of $\mathrm{Cd}$ and $\mathrm{Ni}$ in the soil samples exceeded the background levels for the continental crust and the average worldwide soils. In contrast, the remaining heavy metals were within the reported limits (Table 3). Heavy metals concentrations in soils are higher than those observed in the coastal sediments of Abu Dhabi but lower than those for roadside dust (except for Ni and Cd) (Table 3).

Enrichment factor (EF) analysis showed that $\mathrm{Cd}$ was the most enriched element followed by Ni, Zn, Cr, Mn, Co and As (Figure 5).

According to the enrichment classification [75], the low EF levels for As (0.06) and Co (0.19) suggest that they are entirely originated from the crustal materials or natural processes, as they may release during the weathering and erosion of igneous rocks. These metals are transported and deposited by atmospheric mineral dust due to frequent and 
active dust storms. However, $\mathrm{Cd}$ (60.53), Ni (21.31), Zn (8.06), and $\mathrm{Cr}$ (6.16) are highly enriched in soils. They could originate from non-crustal sources. The use of phosphoric fertilizers can add $\mathrm{Cd}$ and $\mathrm{Pb}$ to the soil [76] and the vehicles' exhaust as the area is surrounded by major highways. $\mathrm{Pb}$ (3.67) and $\mathrm{Mn}$ (3.18) are moderately enriched and mainly derived from various sources, with the natural one being the major contributor. $\mathrm{Pb}$ can be attributed to the vehicle exhausts (because the leaded gasoline is used for trucks loading/unloading) and the dry deposition.

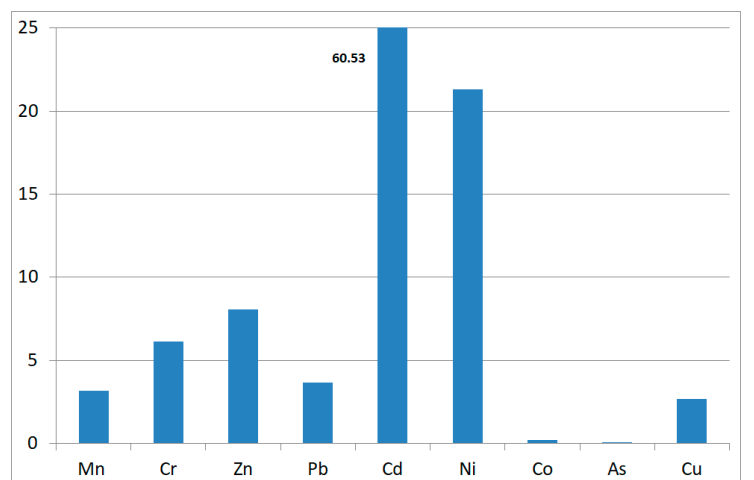

(a)

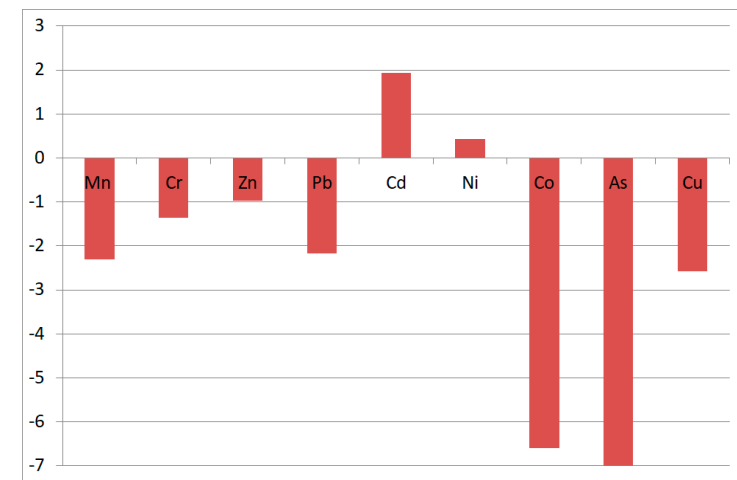

(b)

Figure 5. The average (a) geo-accumulation index $\left(\mathrm{I}_{\text {geo }}\right),(\mathbf{b})$ enrichment factors (EF)relative to the average upper continental crust for heavy metals in the soil samples collected from Liwa, Abu Dhabi, UAE.

$\mathrm{Zn}$ can be associated with vehicular emissions such as combustion of petrol, wearing of tires and brake linings. In addition to anthropogenic sources, $\mathrm{Cr}$ content values in soil samples (compared to world soil average content of $\mathrm{Cr}$ ) also suggest that $\mathrm{Cr}$ is derived from the chemical weathering of basalt exposed in the region and carried through atmospheric dust. Cr concentration of about $170 \mathrm{mg} / \mathrm{kg}$ was measured in basalt [77], whereas the average crustal abundance is $100 \mathrm{mg} / \mathrm{kg}$ [49]. The relative low Cu content in soil indicates natural sources, with a minor contribution of anthropogenic sources such as fungicide and pesticides enriched in $\mathrm{Cu}$ [78]. High concentrations of Ni were observed in soil samples that might be related to the fuel additive [79], where diesel-powered trucks are loading/unloading materials (crops, fertilizers, etc.), among other sources already described.

Based on Muller scales [51], the soil samples are uncontaminated with $\mathrm{Mn}, \mathrm{Cr}, \mathrm{Zn}$, $\mathrm{Pb}, \mathrm{Co}, \mathrm{As}, \mathrm{Cu}$ (with $\mathrm{I}_{\text {geo }}$ of $-2.31,-1.36,-0.97,-2.17,-6.59,-8.14$ and -2.57 ). Soils are uncontaminated to moderately contaminated with $\mathrm{Ni}\left(\mathrm{I}_{\text {geo }}=0.43\right)$ and moderately contaminated with $\mathrm{Cd}\left(\mathrm{I}_{\text {geo }}=1.94\right)$ (Figure 6 and Table 4$)$. Heavy metals are ranked in the following order (based on $\mathrm{I}_{\text {geo }}$ ): $\mathrm{Cd}>\mathrm{Ni}>\mathrm{Zn}>\mathrm{Cr}>\mathrm{Pb}>\mathrm{Mn}>\mathrm{Cu}>\mathrm{Co}>$ As (Figure 6 and Table 4).

The CF of metals in soil samples (Table 4) indicates low contamination, except for Ni, which shows moderate contamination. Based on the $\mathrm{CF}$, heavy metals are ranked in the following order: $\mathrm{Cd}>\mathrm{Ni}>\mathrm{Zn}>\mathrm{Cr}>\mathrm{Pb}>\mathrm{Mn}>\mathrm{Cu}>\mathrm{Co}>$ As.

The average PLI values indicated unpolluted to slightly polluted soils samples (Table 4). The results of PERI of heavy metals in the soil (Table 4) revealed that the single ecological risks $\left(\mathrm{E}_{\mathrm{i}}\right)$ of heavy metals were ranked in the following order: $\mathrm{Cd}>\mathrm{Ni}>\mathrm{Pb}>\mathrm{Cu}>\mathrm{Cr}>\mathrm{Zn}$ $>\mathrm{Mn}>\mathrm{Co}>\mathrm{As}$. All heavy metals have $\mathrm{E}_{\mathrm{i}}$ values indicating low risk, except for $\mathrm{Cd}$, which possesses a high ecological risk. The PERI in soils ranged from 152.63 to 224.39 with an average of 189.28 (Figure 5). These values indicate a moderate potential ecological risk [54].

The percent contribution of individual metal to overall PERI is shown in Figure 6. It relevels that $\mathrm{Cd}$ accounts for approximately $91.6 \%$ of the total ecological risk, whereas $\mathrm{Ni}$ represents about $5.6 \%$, and the remaining heavy metals compromise $2.8 \%$ only. These results indicate that $\mathrm{Cd}$ primarily pose the high ecological risk as they contribute $97.2 \%$ to the total potential ecological risk in the soils. 
The high variation coefficients of certain heavy metals (such as $\mathrm{Pb}$ and $\mathrm{Co}$ ) showed values larger than $30 \%$, suggesting that they were probably derived from different emission sources. These metals probably originated from multiple sources, of which some are common (as discussed earlier). Some metals are released from natural sources and enriched by anthropogenic activities, such as traffic-related emissions, agriculture, and fuel combustion.

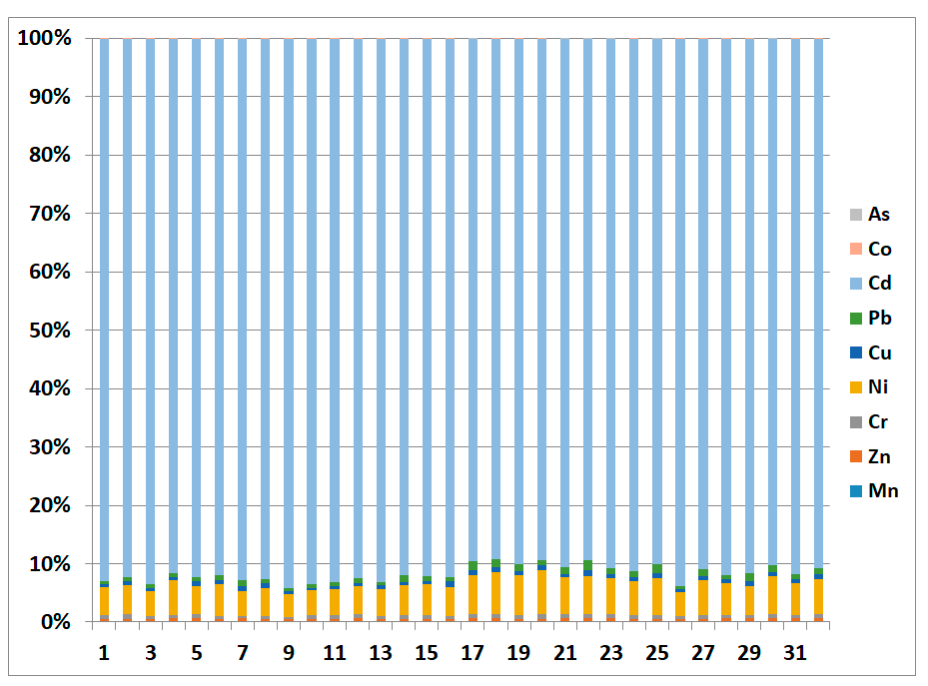

Figure 6. Contribution of heavy metals to the $E_{i}$ in soil samples, Liwa, UAE.

Table 4. Basic statistics of the contamination factor (CF), pollution load index (PLI), single ecological risk index $\left(\mathrm{E}_{\mathrm{i}}\right)$, and PERI for heavy metals in the soils from Liwa, Abu Dhabi.

\begin{tabular}{ccccccccccc}
\hline & & & \multicolumn{1}{c}{$\mathbf{C F}$} & & & & & PLI \\
\hline Mn & $\mathbf{Z n}$ & $\mathbf{C r}$ & $\mathbf{N i}$ & $\mathbf{C u}$ & $\mathbf{P b}$ & $\mathbf{C d}$ & $\mathbf{C o}$ & $\mathbf{A s}$ & \\
\hline Min & 0.24 & 0.61 & 0.43 & 1.64 & 0.19 & 0.19 & 4.61 & 0.00 & 0.00 & 0.19 \\
\hline Max & 0.35 & 0.96 & 0.72 & 2.61 & 0.39 & 0.59 & 6.92 & 0.04 & 0.01 & 0.39 \\
\hline SD & 0.03 & 0.11 & 0.08 & 0.30 & 0.05 & 0.12 & 0.65 & 0.01 & 0.00 & 0.04 \\
\hline & & & & & $\mathbf{E}_{\mathbf{i}}$ & & & & & PERI \\
\hline Mean & 0.30 & 0.77 & 1.18 & 10.21 & 1.29 & 1.76 & 173.63 & 0.09 & 0.05 & 189.28 \\
\hline Min & 0.24 & 0.61 & 0.87 & 8.22 & 0.94 & 0.94 & 138.31 & 0.02 & 0.05 & 152.63 \\
\hline Max & 0.35 & 0.96 & 1.43 & 13.03 & 1.97 & 2.95 & 207.63 & 0.18 & 0.06 & 224.39 \\
\hline SD & 0.02 & 0.11 & 0.16 & 1.44 & 0.24 & 0.57 & 18.60 & 0.04 & 0.00 & 18.26 \\
\hline & & & & & $\mathbf{I}_{\text {geo }}$ & & & & & \\
\hline Mean & -2.31 & -0.97 & -1.36 & 0.43 & -2.57 & -2.17 & 1.94 & -6.59 & -8.14 & \\
\hline Min & -2.62 & -1.31 & -1.79 & 0.13 & -3.00 & -2.99 & 1.62 & -8.75 & -8.29 & \\
\hline Max & -2.12 & -0.65 & -1.07 & 0.80 & -1.93 & -1.35 & 2.21 & -5.34 & -7.88 & \\
\hline SD & 0.12 & 0.20 & 0.20 & 0.20 & 0.26 & 0.46 & 0.16 & 0.88 & 0.09 & \\
\hline
\end{tabular}

\section{Conclusions}

This study provides valuable data about heavy metal contents in soils from Liwa (Abu Dhabi). Liwa is of prime importance as it is a major food production area of the country. A previous study had shown that the major groundwater aquifer located beneath the extensive agriculture area lies within high to very high pollution vulnerability zones. This also indicates that heavy metals in soils may leach with agricultural runoff to end up in groundwater. The composition of soils revealed generally much greater concentrations 
for $\mathrm{Mn}, \mathrm{Zn}, \mathrm{Cr}$, and Ni compared to other metals, but only the concentration of Cd in soil samples exceed the background levels for the continental crust and the average worldwide soils. Even if $\mathrm{Cd}, \mathrm{Ni}, \mathrm{Zn}$, and $\mathrm{Cr}$ are highly enriched in soils, the pollution indices generally showed that the soils are uncontaminated with the majority of heavy metals except for $\mathrm{Ni}$ and $\mathrm{Cd}$. The ecological risk assessment revealed a low risk to local ecosystems, except for $\mathrm{Cd}$.

Author Contributions: Conceptualization, writing - original draft preparation and methodology, A.A.A.-T. and Y.N.; software and validation, A.B.; formal analysis, J.I. and N.B.O.; investigation and resources, C.M.X.; writing-review and editing, A.B., M.S., C.-S.D. and F.M.H.; project administration and funding acquisition A.A.A.-T.; Visualization, M.S. All authors have read and agreed to the published version of the manuscript.

Funding: This project was funded by the Research Office, Zayed University, the United Arab Emirates (Project No. R 17041).

Institutional Review Board Statement: Not Applicable.

Informed Consent Statement: Not Applicable.

Data Availability Statement: The raw data supporting the conclusions of this article will be made available by the authors, without undue reservation.

Conflicts of Interest: The authors declare no conflict of interest.

\section{References}

1. Howari, F.M.; Abu-Rukah, Y.; Goodell, P.C. Heavy metal pollution of soils along North Shuna-Aqaba Highway, Jordan. Int. J. Environ. Pollut. 2004, 22, 597-607. [CrossRef]

2. Al-Taani, A.A.; Nazzal, Y.; Howari, F.M. Assessment of heavy metals in roadside dust along the Abu Dhabi-Al Ain National Highway, UAE. Environ. Earth Sci. 2019, 78, 411. [CrossRef]

3. Al-Taani, A.A.; Nazzal, Y.; Howari, F.M.; Yousef, A. Long-term trends in ambient fine particulate matter from 1980 to 2016 in United Arab Emirates. Environ. Monit. Assess. 2019, 191, 143. [CrossRef] [PubMed]

4. Barbeş, L.; Bărbulescu, A. Monitoring and statistical assessement of heavy metals in soil and leaves of Populus nigra L. Environ. Eng. Manag. J. 2017, 16, 187-196.

5. Barbeş, L.; Bărbulescu, A.; Rădulescu, C.; Stihi, C. Determination of heavy metals in leaves and bark of Populus nigra L. Rom. Rep. Phys. 2014, 66, 877-886.

6. Barbeş, L.; Bărbulescu, A.; Stanciu, G. Statistical analysis of mineral elements content in different melliferous plants from the Dobrogea region, Romania. Rom Rep. Phys. 2020, 72, 705.

7. Rădulescu, C.; Stihi, C.; Barbeş, L.; Chilian, A.; Chelărescu, D.E. Studies concerning heavy metals accumulation of Carduus nutans L. and Taraxacum officinale as potential soil bioindicator species. Rev. Chim. 2013, 64, 754-760.

8. Aguilera, I.; Daponte, A.; Gil, F.; Hernández, A.F.; Godoy, P.; Pla, A.; Ramos, J.L. Urinary levels of arsenic and heavy metals in children and adolescents living in the industrialised area of Ria of Huelva (SW Spain). Environ. Int. 2010, 36, 563-569. [CrossRef]

9. Ljung, K.; Selinus, O.; Otabbong, E. Metals in soils of children's urban environments in the small northern European city of Uppsala. Sci. Total Environ. 2006, 366, 749-759. [CrossRef] [PubMed]

10. Bărbulescu, A.; Postolache, F. New approaches for modeling the regional pollution in Europe. Sci. Total Environ. 2021, 753, 141993. [CrossRef]

11. Al-Taani, A.A.; Al-Qudah, K.A. Investigation of desert subsoil nitrate in Northeastern Badia of Jordan. Sci. Total Environ. 2013, 442, 111-115. [CrossRef]

12. Poggio, L.; Vrščaj, B.; Schulin, R.; Hepperle, E.; Ajmone Marsan, F. Metals pollution and human bioaccessibility of topsoils in Grugliasco (Italy). Environ. Pollut. 2008, 157, 680-689. [CrossRef]

13. Vimercati, L.; Baldassarre, A.; Gatti, M.F.; Gagliardi, T.; Serinelli, M.; De Maria, L.; Caputi, A.; A Dirodi, A.; Galise, I.; Cuccaro, F.; et al. Non-occupational exposure to heavy metals of the residents of an industrial area and biomonitoring. Environ. Monit. Assess. 2016, 188, 673. [CrossRef] [PubMed]

14. USEPA. Risk Assessment: Technical Background Information. 2002. Available online: https://www.epa.gov/risk/riskassessment-guidance (accessed on 1 December 2020).

15. Lado, L.R.; Hengl, T.; Reuter, H.I. Heavy metals in European soils: A geostatistical analysis of the FOREGS Geochemical database. Geoderma 2008, 148, 189-199. [CrossRef]

16. Wuana, R.A.; Okieimen, F.E. Heavy Metals in Contaminated Soils: A Review of Sources, Chemistry, Risks and Best Available Strategies for Remediation. ISRN Ecol. 2011, 2011, 1-20. [CrossRef]

17. T1eng, Y.; Wu, J.; Lu, S.; Wang, Y.; Jiao, X.; Song, L. Soil and Soil Environmental Quality Monitoring in China: A Review. Environ. Int. 2014, 69C, 177-199. [CrossRef] [PubMed] 
18. Wu, Q.; Leung, J.; Geng, X.; Chen, S.; Huang, X.; Li, H.; Huang, Z.; Zhu, L.; Chen, J.; Lu, Y. Heavy metal contamination of soil and water in the vicinity of an abandoned e-waste recycling site: Implications for dissemination of heavy metals. Sci. Total Environ. 2015, 506, 217-225. [CrossRef] [PubMed]

19. Wu, S.; Peng, S.; Zhang, X.; Wu, D.; Luo, W.; Zhang, T.; Zhou, S.; Yang, G.; Wan, H.; Wu, L. Levels and health risk assessments of heavy metals in urban soils in Dongguan, China. J. Geochem. Explor. 2015, 148. [CrossRef]

20. Streets, D.; Lu, Z.; Levin, L.; Ter schure, A.; Sunderland, E. Historical releases of mercury to air, land, and water from coal combustion. Sci. Total Environ. 2017, 615, 131-140. [CrossRef] [PubMed]

21. Charlesworth, S.; Everett, M.; McCarthy, R.; Ordóñez, A.; de Miguel, E. A comparative study of heavy metal concentration and distribution in deposited street dusts in a large and a small urban area: Birmingham and Coventry, West Midlands, UK Environ. Int. 2003, 29, 563-573. [CrossRef]

22. Weissmannová, H.; Pavlovský, J. Indices of soil contamination by heavy metals-Methodology of calculation for pollution assessment (minireview). Environ. Monit. Assess. 2017, 189. [CrossRef] [PubMed]

23. Bărbulescu, A. Assessing the groundwater vulnerability: DRASTIC method and its versions. A review. Water 2020, 12, 1356. [CrossRef]

24. El-Radaideh, N.; Al-Taani, A.A.; Al Khateeb, W.M. Status of sedimentation in King Talal Dam, case study from Jordan. Environ. Earth Sci. 2017, 76, 132. [CrossRef]

25. El-Radaideh, N.; Al-Taani, A.A.; Al Khateeb, W.M. Characteristics and quality of reservoir sediments, Mujib Dam, Central Jordan, as a case study. Environ. Monit. Assess. 2017, 189, 143. [CrossRef] [PubMed]

26. El-Radaideh, N.; Al-Taani, A. Geo-environmental study of heavy metals of the agricultural highway soils, NW Jordan. Arab. J. Geosci. 2018, 11. [CrossRef]

27. Chrastný, V.; Vaněk, A.; Teper, L.; Cabala, J.; Procházka, J.; Pechar, L.; Drahota, P.; Penížek, V.; Komárek, M.; Novák, M. Geochemical position of $\mathrm{Pb}, \mathrm{Zn}$ and $\mathrm{Cd}$ in soils near the Olkusz mine/ smelter, South Poland: Effects of land use, type of contamination and distance from pollution source. Environ. Monit. Assess. 2012, 184, 2517-2536. [CrossRef] [PubMed]

28. Khlifi, R.; Olmedo, P.; Gil, F.; Feki-Tounsi, M.; Hammami, B.; Rebai, A.; Hamza-Chaffai, A. Biomonitoring of cadmium, chromium, nickel and arsenic in general population living near mining and active industrial areas in Southern Tunisia. Environ. Monit. Assess. 2014, 186, 761-779. [CrossRef]

29. Vimercati, L.; Gatti, M.F.; Gagliardi, T.; Cuccaro, F.; De Maria, L.; Caputi, A.; Quarato, M.; Baldassarre, A. Environmental exposure to arsenic and chromium in an industrial area. Environ. Sci. Pollut. Res. Int. 2017, 24, 11528-11535. [CrossRef]

30. Nazzal, Y.; Rosen, M.; Al-Rawabdeh, A. Assessment of metal pollution in urban road dusts from selected highways of the Greater Toronto Area in Canada. Environ. Monit. Assess. 2012, 185. [CrossRef] [PubMed]

31. Guillén, M.T.; Delgado, J.; Albanese, S.; Nieto, J.M.; Lima, A.; De Vivo, B. Environmental geochemical mapping of Huelva municipality soils (SW Spain) as a tool to determine background and baseline values. J. Geochem. Explor. 2011, 109, 59-69. [CrossRef]

32. Pastor, J.; Hernández, A.J. Heavy metals, salts and organic residues in old solid urban waste landfills and surface waters in their discharge areas: Determinants for restoring their impact. J. Environ. Manag. 2011, 95, S42-S49. [CrossRef]

33. Wang, Y.; Sikora, S.; Kim, H.; Dubey, B.; Townsend, T. Mobilization of iron and arsenic from soil by construction and demolition debris landfill leachate. Waste Manag. 2011, 32, 925-932. [CrossRef]

34. Werkenthin, M.; Kluge, B.; Wessolek, G. Metals in European Roadside Soils and Soil solution—A Review. Environ. Pollut. 2014, 189C, 98-110. [CrossRef]

35. El-Radaideh, N.; Al-Taani, A.A.; Al-Momani, T.; Tarawneh, K.; Batayneh, A.; Taani, A. Evaluating the potential of sediments in Ziqlab Reservoir (northwest Jordan) for soil replacement and amendment. Lake Reserv. Manag. 2014, 30, 32-45. [CrossRef]

36. Al-Taani, A.; Batayneh, A.; El-Radaideh, N.; Ghrefat, H.; Zumlot, T.; Al-Rawabdeh, A.; Momani, T.; Taani, A. Spatial Distribution and Pollution Assessment of Trace Metals in Surface Sediments of Ziqlab Reservoir, Jordan. Environ. Monit. Assess. 2015, 187, 1-14. [CrossRef]

37. Al-Taani, A.A.; Rashdan, M.; Khashashneh, S. Atmospheric dry deposition of mineral dust to the Gulf of Aqaba, Red Sea: Rate and trace elements. Mar. Pollut. Bull. 2015, 92, 252-258. [CrossRef]

38. Batayneh, A.T.; Al-Taani, A.A. Integrated resistivity and water chemistry for evaluation of groundwater quality of the Gulf of Aqaba coastal area in Saudi Arabia. Geosci. J. 2016, 20, 403-413. [CrossRef]

39. Nazzal, Y.; Barbulescu, A.; Howari, F.; Yousef, A.; Al-Taani, A.A.; Al Aydaroos, F.; Naseem, M. New insights on sand dust storm from historical records, UAE. Arab. J. Geosci. 2019, 12, 396. [CrossRef]

40. Baran, A.; Wieczorek, J. Application of geochemical and ecotoxicity indices for assessment of heavy metals content in soils. Arch. Environ. Prot. 2015, 41, 54-63. [CrossRef]

41. Baran, A.; Wieczorek, J.; Mazurek, R.; Urbański, K.; Klimkowicz-Pawlas, A. Potential ecological risk assessment and predicting zinc accumulation in soils. Environ. Geochem. Health 2018, 40, 435-450. [CrossRef] [PubMed]

42. Wieczorek, J.; Baran, A.; Urbański, K.; Mazurek, R.; Klimowicz-Pawlas, A. Assessment of the pollution and ecological risk of lead and cadmium in soils. Environ. Geochem. Health 2018, 40, 2325-2342. [CrossRef] [PubMed]

43. Sutkovska, K.; Teper, L.; Czech, T.; Hulok, T.; Olszak, M.; Zogala, J. Quality of Peri-Urban Soil Developed from Ore-Bearing Carbonates: Heavy Metal Levels and Source Apportionment Assessed Using Pollution Indices. Minerals 2020, 10, 1140. [CrossRef] 
44. Fragaszy, S.; Mcdonnell, R. Oasis At a Crossroads: Agriculture and Groundwater in Liwa, United Arab Emirates. 2016. Available online: http:/ /gw-mena.iwmi.org/wp-content/uploads/sites/3/2017/04/Rep.15-Groundwater-governance-in-Liwa-oasisreport_final_cover.pdf (accessed on 1 December 2020).

45. Al-Katheeri, E.S.; Howari, F.M.; Murad, A.A. Hydrogeochemistry and pollution assessment of quaternary-tertiary aquifer in the Liwa area, United Arab Emirates. Environ. Earth Sci. 2009, 59, 581. [CrossRef]

46. Iqbal, J.; Nazzal, Y.; Howari, F.; Xavier, C.; Yousef, A. Hydrochemical processes determining the groundwater quality for irrigation use in an arid environment: The case of Liwa Aquifer, Abu Dhabi, United Arab Emirates. Groundw. Sustain. Dev. 2018, 7, $212-219$. [CrossRef]

47. Sinex, S.A.; Helz, G.R. Regional geochemistry of trace elements in Chesapeake Bay sediments. Environ. Geol. 1981, 3, 315-323. [CrossRef]

48. Clemente, R.; Walker, D.; Pilar Bernal, M. Uptake of heavy metals and As by Brassica juncea grown in a contaminated soil in Aznalcóllar (Spain): The effect of soil amendments. Environ. Pollut. 2005, 138, 46-58. [CrossRef]

49. Kabata-Pendias, A.; Pendias, H. Trace Elements in Soils and Plants, 3rd ed.; CRC Press: New York, NY, USA, 2001.

50. Zhang, J.; Liu, C.L. Riverine Composition and Estuarine Geochemistry of Particulate Metals in China-Weathering Features, Anthropogenic Impact and Chemical Fluxes. Estuar. Coast. Shelf Sci. 2002, 54, 1051-1070. [CrossRef]

51. Müller, G. The Heavy Metal Pollution of the Sediments of Neckars and its Tributary: A Stocktaking. Chem. Zeitung 1981, 105, 157-164.

52. Fortescue, J.A. Landscape geochemistry: Retrospect and prospect. Appl. Geochem. 1992, 7, 1-53. [CrossRef]

53. Chen, T.-B.; Zheng, Y.-M.; Lei, M.; Huang, Z.-C.; Wu, H.-T.; Chen, H.; Fan, K.-K.; Yu, K.; Wu, X.; Tian, Q.-Z. Assessment of heavy metal pollution in surface soils of urban parks in Beijing, China. Chemosphere 2005, 60, 542-551. [CrossRef]

54. Håkanson, L. An Ecological Risk Index for Aquatic Pollution Control-A Sedimentological Approach. Water Res. 1980, $14,975-1001$. [CrossRef]

55. Salomons, W.; Förstner, U. Metals in the Hydrocycle; Springer: Berlin/Heidelberg, Germany, 1984.

56. Tomlinson, D.L.; Wilson, J.G.; Harris, C.R.; Jeffrey, D.W. Problems in the assessment of heavy-metal levels in estuaries and the formation of a pollution index. Helgoländer Meeresunters. 1980, 33, 566-575. [CrossRef]

57. Angulo, E. The Tomlison Pollution Load Index applied to heavy metal, 'Mussel-Watch' data: A useful index to assess coastal pollution. Sci. Total Environ. 1996, 187, 19-56. [CrossRef]

58. Roberts, T.L. Cadmium and Phosphorous Fertilizers: The Issues and the Science. Procedia Eng. 2014, 83, 52-59. [CrossRef]

59. Basta, N.; Ryan, J.A.; Chaney, R. Trace Element Chemistry in Residual-Treated Soil: Key Concepts and Metal Bioavailability. J. Environ. Qual. 2005, 34, 49-63. [CrossRef] [PubMed]

60. McLaren, S.; Aljuaidi, F.; Bateman, M.; Millington, A. First evidence for episodic flooding events in the arid interior of central Saudi Arabia over the last 60 ka. J. Quat. Sci. 2009, 24, 198-207. [CrossRef]

61. Gonçalvès, J.; Petersen, J.; Deschamps, P.; Hamelin, B.; Baba-Sy, O. Quantifying the modern recharge of the "fossil" Sahara aquifers. Geophys. Res. Lett. 2013, 40, 2673-2678. [CrossRef]

62. Teh, T.; Norulaini, N.; Shahadat, M.; WONG, Y.; Kadir, M. Risk Assessment of Metal Contamination in Soil and Groundwater in Asia: A Review of Recent Trends as well as Existing Environmental Laws and Regulations. Pedosphere 2016, 26, 431-450. [CrossRef]

63. Yaroshevsky, A. Abundances of chemical elements in the Earth's crust. Geochem. Int. 2006, 44, 48-55. [CrossRef]

64. Mcbride, M.; Cherney, J. Molybdenum, Sulfur, and Other Trace Elements in Farm Soils and Forages After Sewage Sludge Application. Commun. Soil Sci. Plant Anal. 2004, 35, 517-535. [CrossRef]

65. McBride, M.B. Toxic metals in sewage sludge-amended soils: Has promotion of beneficial use discounted the risks? Adv. Environ. Res. 2003, 8, 5-19. [CrossRef]

66. Chaney, R.L.; Reeves, R.D.; Baklanov, I.A.; Centofanti, T.; Broadhurst, C.L.; Baker, A.J.; Van der Ent, A.; Roseberg, R.J. Phytoremediation and phytomining: Using plants to remediate contaminated or mineralized environments. In Phytoremediation and Phytomining: Using Plants to Remediate Contaminated or Mineralized Environments; US Department of Agriculture: Beltsville, MD, USA, 2014; pp. 365-391.

67. Fan, Y.; Zhu, T.; Li, M.; He, J.; Huang, R. Heavy Metal Contamination in Soil and Brown Rice and Human Health Risk Assessment near Three Mining Areas in Central China. J. Healthc. Eng. 2017, 2017, 1-9. [CrossRef] [PubMed]

68. Yan, G.; Mao, L.; Liu, S.; Mao, Y.; Ye, H.; Huang, T.; Li, F.; Chen, L. Enrichment and sources of trace metals in roadside soils in Shanghai, China: A case study of two urban/rural roads. Sci. Total Environ. 2018, 631, 942-950. [CrossRef]

69. Padoan, E.; Romè, C.; Ajmone-Marsan, F. Bioaccessibility and size distribution of metals in road dust and roadside soils along a peri-urban transect. Sci. Total Environ. 2017, 601-602, 89-98. [CrossRef] [PubMed]

70. Wiseman, C.L.S.; Zereini, F.; Püttmann, W. Metal and metalloid accumulation in cultivated urban soils: A medium-term study of trends in Toronto, Canada. Sci. Total Environ. 2015, 538, 564-572. [CrossRef] [PubMed]

71. Rashdi, S.; Arabi, A.; Howari, F.; Siad, A. Distribution of heavy metals in the coastal area of Abu Dhabi in the United Arab Emirates. Mar. Pollut. Bull. 2015, 97. [CrossRef]

72. Farahat, A. Air pollution in the Arabian Peninsula (Saudi Arabia, the United Arab Emirates, Kuwait, Qatar, Bahrain, and Oman): Causes, effects, and aerosol categorization. Arab. J. Geosci. 2016, 9. [CrossRef] 
73. EAD (Environment Agency of Abu Dhabi). Waste and Pollution Sources of Abu Dhabi Emirate, State of Environment, Abu Dhabi, UAE; Environment Agency of Abu Dhabi: Abu Dhabi, United Arab Emirates, 2008.

74. Ministry of Presidential Affairs. Dust sources affecting the United Arab Emirates; National Center of Meteorology and Seismology, Ministry of Presidential Affairs: Abu Dhabi, United Arab Emirates, 2011.

75. Sutherland, R.A. Bed sediment-associated trace metals in an urban stream, Oahu, Hawaii. Environ. Geol. 2000, 39, 611-627. [CrossRef]

76. Mmolawa, K.B.; Likuku, A.S.; Gaboutloeloe, G.K. Assessment of heavy metal pollution in soils along major roadside areas in Botswana. Afr. J. Environ. Sci. Technol. 2011, 5, 186-196. [CrossRef]

77. Mielke, J. Composition of the Earth's Crust and Distribution of the Elements. Rev. Res. Mod. Probl. Geochem. 1979, $16,13-37$.

78. Jones, L.H.P.; Jarvis, S.C. The fate of heavy metals. In The Chemistry of Soil Processes; John Wiley \& Sons: New York, NY, USA, 1981.

79. Loranger, S.; Zayed, J.; Kennedy, G. Contribution of methylcyclopentadienyl manganese tricarbonyl (MMT) to atmospheric Mn concentration near expressway: Dispersion modeling estimations. Atmos. Environ. 1995, 29, 591-599. [CrossRef] 